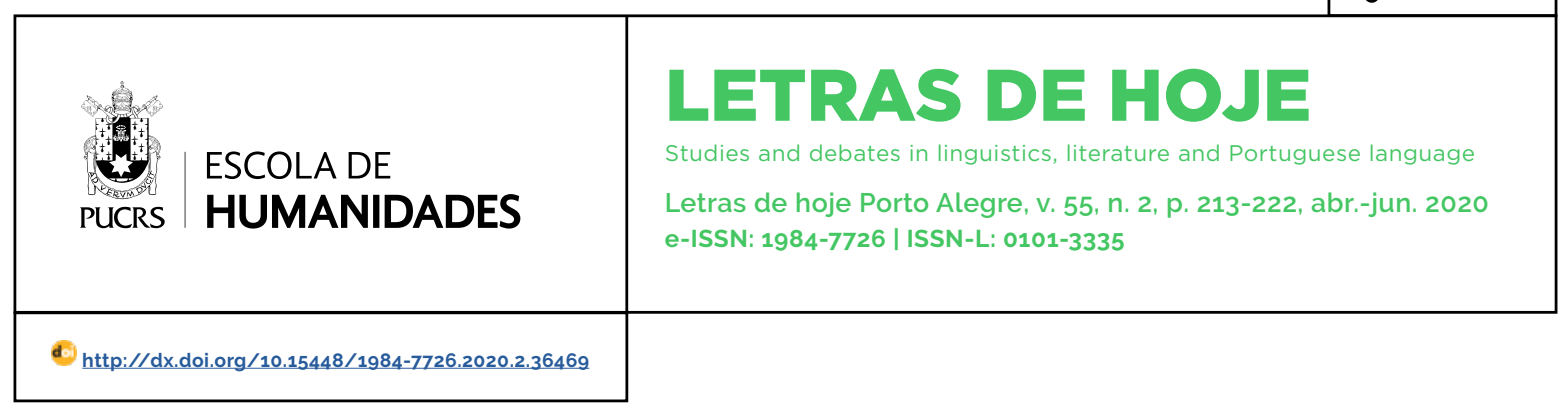

SEÇÃO: TEMÁTICA LIVRE

\title{
A condição judaica no processo de criação literária de Cíntia Moscovich e Michel Laub1
}

\author{
The Jewish condition in the process of literary creation of Cintia Moscovich and Michel Laub \\ La condición judia en el proceso de creación literaria de Cíntia Moscovich y Michel Laub
}

\section{Luiz Antonio de Assis \\ Brasil ${ }^{1}$}

orcid.org/0000-0003-2422-7739

laab@pucrs.br

Daniel Fernando Gruber ${ }^{1}$ orcid.org/0000-0002-8294-0172 df.gruber@gmail.com

\section{Bibiana Barrios Simionatto ${ }^{1}$}

orcid.org/0000-0003-4655-073X bibianabsimionatto@gmail.com

Frederico Dollo Linardi ${ }^{1}$ orcid.org/0000-0002-3808-7100 frederico.linardi@acad.pucrs.br

\section{María Elena Morán}

Atencio ${ }^{1}$

orcid.org/0000-0003-2492-9810 marielenamoran@gmail.com

\section{Mariana Pessah ${ }^{1}$}

orcid.org/0000-0002-9408-1918 marianpessah@gmail.com

Stéfanie Garcia Medeiros ${ }^{1}$ orcid.org/0000-0002-3691-3405 stefanie_medeiros@hotmail.com

Recebido em: 20 nov. 2019. Aprovado em: 04 jun. 2020. Publicado em: 11 Set. 2020.

\section{(c) (1)}

Artigo está licenciado sob forma de uma licença Creative Commons Atribuição 4.0 Internacional.
Resumo: Neste artigo são investigadas as caracteristicas da condição judaica na obra de dois escritores judeus brasileiros contemporâneos: Cintia Moscovich e Michel Laub. Por meio da leitura das obras Por que sou gorda, mamãe? (2006) e Diário da queda (2011), as características da identidade judaica encontradas nas narrativas são comparadas com a posição dos próprios autores, conhecida através de entrevistas realizadas em setembro de 2018. Tanto as respostas da entrevista quanto a observação dos textos literários são interpretadas à luz de A condição judaica (1985), de Moacyr Scliar. Conclui-se que a identidade judaica não é um dado biológico/hereditário nem religioso, compondo-se a partir de marcos culturais, como costumes, rituais, fala, humor e alimentação, e que a presença desses elementos ou o pertencimento de autores ao judaísmo não condiciona uma obra, por si, como literatura judaica.

Palavras-chave: Judaismo. Literatura judaica. Literatura brasileira contemporânea. Processo criativo.

Abstract: In this work are investigate the characteristics of the Jewish condition in the work of two contemporary Brazilian Jewish writers: Cintia Moscovich and Michel Laub. By reading the novels Por que sou gorda, mamãe? (2006) and Diário da queda (2011), the characteristics of Jewish identity found in the narratives are compared with the position of the authors themselves, known through interviews conducted in September 2018. Both interview responses and observation of literary texts are interpreted in the light of Moacyr Scliar's A condição Judaica (1985). It is concluded in this work that the Jewish identity is not a biological / hereditary or religious data, composing itself from cultural landmarks, such as customs, rituals, speech, humor and food, and that the presence of these elements or belonging of authors to Judaism does not condition a work, by itself, as Jewish literature.

Keywords: Judaism. Jewish literature. Contemporary Brazilian literature. Creative process.

Resumen: Este artículo investiga las caracteristicas de la condición judia en el trabajo de dos escritores judios brasileños contemporáneos Cintia Moscovich y Michel Laub. A través de la lectura de las obras Por que sou gorda, mamãe? (2006) y Diário da queda (2011), las características de la identidad judia encontradas en las narraciones se comparan con la posición de los propios autores, conocidas a través de entrevistas realizadas en septiembre de 2018. Tanto las respuestas de la entrevista como la observación de los textos literarios son interpretados a la luz de A condição judaica (1985), por Moacyr Scliar. Se concluye que la identidad judia no es un dato biológico / hereditario ni religioso, que se compone de hitos culturales, como costumbres, rituales, habla, humor y comida, y que la presencia de estos elementos o la pertenencia de los autores al judaísmo no condiciona una obra, per se, como la literatura judía.

Palabras-clave: Judaísmo. Literatura judía. Literatura brasileña contemporánea. Proceso creativo. 


\section{Introdução}

O pensamento judaico é responsável por um sem número de obras filosóficas, científicas, históricas, artísticas e literárias. Não se está a dizer que são expressões que tratem diretamente deste tema, embora algumas se dediquem a isso. Na literatura, esse viés será maior ou menor, dependendo do grau de compromisso de seu autor: há os que desenvolvem uma longa carreira sem que se sentirem convocados a isso, mas há outros, e não são poucos, em que a condição judaica aparece de alguma forma, consubstanciada na figura de uma ou de mais personagens.

Este artigo é o resultado de uma pesquisa realizada por um grupo de docentes e discentes do Programa de Pós-Graduação em Letras da Pontifícia Universidade Católica do Rio Grande do Sul empenhados em verificar, em duas ficções (Por que sou gorda, mamãe? e Diário da queda, respectivamente de Cintia Moscovich, 2006, e Michel Laub, 2011), como nelas transparece a questão judaica, suas modalizações, e como se dá sua transposição para a literatura - portanto, como ocorre o processo criativo dessas obras.

Os termos dessa busca encontram-se na obra ensaística A condição judaica (1985) do escritor Moacyr Scliar, que norteou as reflexões e as entrevistas realizadas com os dois autores do corpus. ${ }^{3}$

\section{Pensando a condição judaíca}

Muitos historiadores, antropólogos e escritores podem discordar sobre o que seria uma possivel condição judaica essencial, mas é unânime afirmar que judeus não são uma raça. Em A condição judaica, Moacyr Scliar (1985, p. 26) diz: "Não temos caracteres biológicos comuns, a não ser quando se toma os grupos de determinadas regiões". Na mesma página, para expandir sua ideia, ele complementa: "Comprova-o a heterogeneidade dos tipos judaicos, testemunho da Diáspora e que se traduz não apenas na diversidade de aparência física, mas nos costumes e na língua".

Assim, a condição judaica é, antes de mais nada, cultural. Para encontrar uma essência, Scliar parte do seguinte questionamento:
Quem é judeu? Para os rabinos ortodoxos, judeu é quem nasce do ventre de mãe judia. Esta interpretação tem gerado não poucas polêmicas, inclusive em Israel, onde a religião tem força de lei, e evidentemente não caracteriza a condição judaica, uma categoria emocional e/ou existencial, muito mais ampla e que resulta de uma identificação pessoal com um grupamento que tem muitas coisas em comum (SCLIAR, 1985, p. 27-28).

O judaísmo, para ele, pode ser visto como um grupo étnico, caracterizado por um passado histórico em comum e tradições específicas, cultivadas ao longo do tempo. Há também, "mesmo que negativo", um comprometimento com o Estado de Israel, frente ao qual o judeu dificilmente é indiferente. No entanto, é indispensável notar que a questão fundamental do judaísmo como tradição cultural perpassa obrigatoriamente a literatura, embora não haja um consenso de como definir uma literatura judaica: ela provém do simples fato de ser produzida por um autor judeu ou se manifesta na elaboração de características judaicas - tais como personagens e costumes?

Scliar remete à obra de Kafka para demonstrar o problema: o escritor tcheco, embora judeu, escrevia em alemão e nunca abordou personagens explicitamente judeus em sua obra. "Os personagens não são judeus, não há descrições de costumes judaicos e muito menos expressões em iídiche" (SCLIAR, 1985. p. 74). No entanto, de acordo com o autor, quando se busca o subtexto da literatura kafkiana, o oculto, característico de sua escrita, percebe-se a relevante manifestação de um judaísmo.

De forma análoga, a condição judaica é reflexão fundamental para o narrador-protagonista de Diário da queda, romance de Michel Laub. A identidade imigrante e o ressentimento pós-guerra do avô e do pai do personagem são transmitidos a ele por meio de histórias que se repetiam e que "meu pai as contava da mesma forma, com a mesma entonação, e até hoje sou capaz de citar exemplos que volta e meia deixavam a voz dele embargada" (LAUB, 2011, p. 32).

Sua relação com o mundo é marcada por um trágico acidente envolvendo um colega de escola gói, isto é, não-judeu, em uma escola judia, e seu mundo é situado a partir desse ponto:...

3 As entrevistas foram realizadas na PUCRS em setembro de 2018 
porque eu não tinha nada em comum com aquelas pessoas além do fato de ter nascido judeu, e nada sabia daquelas pessoas além do fato de elas serem judias, e por mais que tanta gente tivesse morrido em campos de concentração não fazia sentido que eu precisasse lembrar disso todos os dias (LAUB, 2011, p. 32).

Também para a narradora-protagonista da obra de Cíntia Moscovich, Por que sou gorda, mamãe?, o judaísmo é uma espécie de herança imposta pelas gerações de sua família. Diz ela: "Sou tão órfã de antepassados. Um broto arrancado à planta. Recordo, porque a memória é a melhor parte desse espólio desconjuntado. E cada lembrança de vovó é, de repente, uma novidade, longe do frio cinzento que estica as garras e rouba" (MOSCOVICH, 2007, p. 55).

Tanto para Cintia Moscovich quanto para Michel Laub essa condição se define por fatores externos ao sujeito. Para Moscovich, "Ninguém nasce judeu. Ninguém chora já em iídiche. Muito embora eu tenda a achar que existe um primeiro choro em iidiche" (MOSCOVICH, 2018, informação oral)4, pois a condição judaica é uma construção cultural imposta. Para Laub, essa discussão entre cultural e racial não apenas é prejudicial aos judeus, no sentido de que as teorias eugenistas do início do século XX levaram ao genocídio do povo por nazistas, como tem sido superada pela ciência contemporânea. Ele entende que "O humanismo está do lado dessa teoria e eu abraço essa teoria até por uma questão quase de sobrevivência [...], é muito dificil para um judeu que ele abrace qualquer tipo de teoria racial em termos de diferenças inatas" (LAUB, 2018, informação oral).

Contudo, uma vez que a condição judaica fornece informações e estímulos para a construção da identidade, um sentimento atávico responde a ela, conforme afirma Moscovich, um sentimento de pertencimento: "alguma coisa que te antecedia, e esses estímulos externos de, sei lá, familia, de alimento, de tradição, vinham ao encontro dessa espécie de receptáculo de coisa em ti que estava predisposta a receber muito bem esses estímulos" (MOSCOVICH, 2018, informação oral). Entretanto, essa sensação não é algo nato ao judeu. Laub, mesmo enxergando o judaísmo como uma cultura, acredita que há um pequeno elemento étnico para o qual não é possivel fechar os olhos totalmente:

...basta ver o tipo de debate identitário que a gente tem hoje na universidade, nas ciências humanas e tal, e que, ao meu ver, até na própria literatura, um debate que está voltando a um certo essencialismo nessa questão de uma voz autoral do lugar de fala, da posição do autor, e muitas vezes considera que ele necessariamente ele tem autoridade ou não tem autoridade para falar de uma certa condição por ele ter nascido branco, preto, homem, mulher, judeu ou não-judeu, etc. etc. (LAUB, 2018, informação oral).

A tendência das discussões contemporâneas, que converge com a posição de Laub e Moscovich, é de que toda a essencialidade judaica é cultural. Isso porque, como reforça Laub, "é uma visão otimista, quase utópica, de que no fundo elas [as pessoas] podem ser o que quiserem, porque a cultura permite isso" (informação oral).

\section{Memórias: perseguições, traumas, formação econômica e estereótipos}

A complexa história dos judeus envolve desde o trauma resultante das perseguições infligidas a esse povo "marcado pela tragédia" (SCLIAR, 1985. p. 7) até o exemplar modo de reverter as adversidades, de se reorganizar social e economicamente. A preservação da memória é um antídoto tanto para a valorização étnica de grupo quanto para uma sociedade de indivíduos, um modo catártico de lidar com as feridas. Como afirma Beatriz Sarlo (2006, p. 159), "o passado é inevitável e vai além da vontade e da razão. Sua força não pode ser suprimida, exceto pela violência, ignorância ou destruição simbólica e material".

Tendo em vista a constante condição do judeu sem território próprio ou definido, Scliar destaca o sentimento de desamparo para definir essa marca em sua história: "A ancestral sensação da terra estranha, da catástrofe iminente (os temporais da História). A eterna busca de um lugar abrigado, seja este lugar o colo da mãe, a casa paterna ou o Estado protetor" (SCLIAR, 1985, p. 6). Assim, ele carrega o trauma com resiliência e tem consciência

4 Todos os trechos retirados de entrevistas orais serão grafados em itálico neste trabalho. 
desse pesar e dessa força, essa força em constante luta contra os elementos apontados por Sarlo.

Faz-se importante lembrar o que diz Joël Candau (2011, p. 16) ao pontuar que a memória é também uma fonte primordial para o que chamamos de identidade: "A memória, ao mesmo tempo em que nos modela, é também por nós modelada", de modo que estão atreladas a ela as naturais estratégias identitárias, como as representações, as "mito-histórias", as crenças, os ritos, os saberes. Dessa maneira, se torna a identidade em ação, segundo Candau (2011, p. 18), mas pode, ao contrário, "ameaçar, perturbar e mesmo arruinar o sentimento de identidade, tal como mostram os trabalhos sobre as lembranças de traumas e tragédias como, por exemplo, a anamnese de abusos sexuais na infância ou a memória do Holocausto".

De qualquer modo, a ameaça da memória e da identidade pode estar nesse esquecimento ou desconhecimento. Considerando que o judeu vive ainda com o drama da desterritorialização, a preservação da memória conta com as instabilidades dessa matéria imprecisa e dinâmica, inclusive no que diz respeito ao sofrimento. Mesmo com um olhar autocritico, saudosa de uma sociedade de outrora, com mentes que a representam melhor, a narradora do Livro de Cintia Moscovich (2007) reflete sobre a herança do trauma e a recuperação: Nós, os judeus, chegamos a nos orgulhar de nossos muitos pesares, nosso tempo cheio do sacrificio de perseguidos. Verdade seja dita: o Povo Escolhido padece da vaidade do sofrimento - uma vez, tivemos a vaidade do pensamento, mas, na revoada dos séculos em diáspora, minguaram sábios e justos. A imolação dos antepassados tem sido, para nós, mérito pessoal (MOSCOVICH, 2007, p. 147).

Scliar também relembra o estigma do usurário a partir de uma construção difamatória surgida na Idade Média em torno dessa atividade:

A nobreza medieval abominava o dinheiro - e o trabalho (...) A sociedade feudal resolveu o impasse de uma maneira engenhosa. Atribuiu o papel de usurário a um elemento marginal na sociedade, um elemento que pouco podia esperar da vida na terra e muito menos da vida eterna: o judeu. Criou-se assim a figura típica e caricatural do usurário de olhinhos brilhantes, nariz adunco, e dedos em garra (SCLIAR, 1985, p. 33).

A generalização do individuo diferente do meio e daqueles que o observam marca a vida de imigran- tes e, em especial, dos judeus que têm esta como uma característica que se tornou inerente à sua história. Sob o olhar da psicologia social, Ecléa Bosi (2013) fundamenta o processo de estereotipização como resultado da inércia de uma opinião coletiva, que se torna uma aparente verdade individualizada.

Para Bosi, vivemos na ilusão de que conhecemos mais que a infima parcela do ambiente e do tempo que já nos é limitadora e, daquilo que não vivenciamos, julgamos conhecer a partir de relatos e experiências de pessoas a quem confiamos, de modo que "o pensamento e o discurso cotidiano se alimentam dessa segurança social" (2013, p. 115). Essa seria a origem dentro deste mecanismo, seguida de uma estabilização apaziguadora (pois o suposto conhecido tranquiliza mais do que o constante estranho), levando a uma inércia até esse processo "apoderar-se de nossa vida mental" (BOSI, 2013, p. 115).

Dessa forma, além do olhar limitador, que causa prejuizo para ambos os lados - um prejudicado pela ignorância de um contexto mais complexo, formado por partes individuais; outro, sofrendo pelo preconceito, descaso e diferentes graus de violência - são possiveis causadores de traumas. Bosi (2013, p. 117) ainda alerta sobre a força e autoridade do estereótipo, que chega ao ponto de parecer um fato biológico.

\section{Diáspora: imigração, adaptação e sobrevivência}

Scliar afirma que "a história dos judeus é uma história de perseguições, de massacres, de fugas" (1985, p. 27). Portanto, um povo acostumado a perseguições se viu, ao longo da história, obrigado a recomeçar a vida em outros mundos, mesmo os mais distantes.

Essa questão é cara ao romance de Moscovich analisado, que reafirma a importância da comida servida numa mesa farta para revelar afetos e manter as conexões com a pátria deixada para trás. A respeito dos primeiros contatos dos imigrantes judeus com o Novo Mundo e da estranheza provocada pelas situações que decorreram deste contato, a narradora relata: 
A vó, assustada com o mar, depois assustada com o trem, depois assustada com a carroça, com o tamanho dos chifres dos bois, com as cédulas do dinheiro novo - dez contos de réis acomodados nos seios da bisavó -, assustada com sacas de sementes, com rolos de arame farpado, com duas mulas por familia, depois assustada com as cobras, onças, graxains, bugios e com os indios bugres, assustada com o grito de pássaros, com nuvens de gafanhotos, assustada com laranjas caídas dos pés, assustada com o vento minuano batendo e com o sol que se parava num calorão como se sempre fosse meio-dia. Assustada que, mal chegados, nem bem abancados, vinha a notícia de que o império russo movimentava tropas para uma grande guerra na Europa. O bisavô tinha escapado (MOSCOVICH, 2007, p. 59).

Laub também aborda temas relacionados com a diáspora em seu romance:

\begin{abstract}
Meu pai dizia que os judeus sempre devem ter profissões que possam exercer em qualquer circunstância, porque de repente você é forçado a deixar o país onde morou desde sempre e não pode depender de uma lingua que não é falada em nenhum outro lugar, ou do conhecimento de leis que não se aplicam em nenhum outro lugar, então é bom ser médico ou dentista ou engenheiro ou comerciante porque é isso que vai garantir seu sustento independentemente do que os vizinhos digam de você, e eles dizem o que sempre se dirá dos judeus, você que rouba o emprego dos outros, que empresta dinheiro a juros, que explora, que conspira, que ameaça, que oprime (LAUB, 2011, p. 38)
\end{abstract}

Trazendo o tema para um núcleo mais próximo, que compreende as relações de pai, filho e avô, Laub experimenta inverter a questão do preconceito. O acontecimento que dispara o conflito do personagem central de $O$ diário da queda é um incidente em que alunos de uma escola judaica de classe média/alta de Porto Alegre agridem (ainda que de forma involuntária ou acidental) João, único aluno não judeu do local. Acostumado com agressões físicas e morais, João não revida ou se revolta. Pelo contrário, convida os colegas para seu aniversário de 13 anos, idade com grande valor religioso para a comunidade. Assim, Laub traz o tema para os dias atuais, para os descendentes que empreenderam a diáspora, para as novas gerações, adaptadas e estabelecidas dentro das regras e das leis dos novos paises em que habitam.
No seu romance, Moscovich põe um olhar mais ameno sobre as gerações jovens. A autora se utiliza de temas referentes aos antepassados para tratar de uma questão geral: a dificuldade de uma menina gorda se enquadrar aos padrões de beleza impostos. No entanto, as questões do trauma e da Diáspora continuam presentes. Moscovich personaliza essa condição na personagem Dona Dora, uma vizinha da família da narradora. Dora é sobrevivente de um campo de concentração, a única que restara de uma familia riquíssima, depois de passar pelos experimentos sádicos de Mengele. Segundo o pai da narradora, pessoas como Dona Dora, fugitivas da guerra, "havia às pencas, às centenas" (MOSCOVICH, 2007, p. 219):

\begin{abstract}
Viviam trancafiados, dona Dora, o marido e o filho, Jacob, um menino surdo-mudo, esquelético e arredio, de olheiras negras, cabelos arrepiados, braços e pernas muito compridos para um tronco tão miúdo - parecia saido de um filme de terror. (...)

Naquela que deveria ser a sala de visitas, nos veio a maior surpresa. Móveis não havia. Havia prateleiras em todas as paredes, inclusive cobrindo a janela, fechada por tijolos rematados por reboco grosso. Nas prateleiras, dona Dora guardava latas, latas e latas, garrafas, garrafas e garrafas, sacos, sacos e sacos. Óleo, leite condensado, leite em pó, conservas de milho, ervilhas, pepino, grão-de-bico, beterraba, repolho, arroz, feijão, milho, lentilha, farinha, sal, fermento, açúcar, café, vinho, água mineral, macarrão, batatas. Rolos de papel higiênico faziam companhia a barras de sabão. Réstias de cebola e alho pendiam dos cantos das prateleiras, junto a galhos de louro seco e outras ervas que não pude identificar. Também havia caixotes de Melhoral, Vagostesil e Pilulas de Vida do Dr. Ross (MOSCOVICH, 2007, p. 218).
\end{abstract}

Aqui se observa a questão da sobrevivência e constante resgate da reputação - uma reputação manchada por estereótipos. Os judeus foram, historicamente, um povo que deixou sua terra de origem para se espalhar pelo mundo - primeiro Europa, depois América - devido às constantes perseguições sofridas. Como resultado dessa mobilidade constante de seus descendentes, o caráter migratório tornou-se parte da sua identidade (SCLIAR, 1985), e pode ser observado como aspecto recorrente nas obras analisadas. 


\section{Identidade: contestadores, rebeldes e estrangeiros}

Em A identidade cultural na pós-modernidade, Stuart Hall diferencia em categorias à parte o sujeito do lluminismo, o sujeito sociológico e o sujeito pós-moderno. O primeiro, segundo ele, é um individuo totalmente centrado, unificado, dotado das capacidades de razão, de consciência e de ação (HALL, 1992, p. 10). Já o segundo reflete a crescente complexidade do mundo moderno e a consciência de que o seu núcleo interior não é autônomo e autossuficiente, mas formado na relação com outras pessoas, que mediam valores, sentidos e símbolos - a cultura. Trata-se de uma concepção interativa da identidade, pois ela é formada de um "eu real" em constante interação com mundos culturais exteriores (HALL, 1992, p. 11).

O sujeito pós-moderno, por sua vez, é formado pelo colapso dessas duas definições. Ele é caracterizado por não ter uma identidade fixa, essencial ou permanente. Sua identidade, então, torna-se uma celebração móvel, formada e transformada continuamente em relação às formas pelas quais o sujeito é representado ou interpelado nos sistemas culturais que o rodeiam (HALL, 1992, p. 13).

Podem ser notados os traços do sujeito pós-moderno na narradora-personagem de Por que sou gorda, mamãe?, de Cintia Moscovich. A narradora constantemente se indaga sobre o seu lugar, sentindo-se deslocada não só por sua família ser judia, mas também por ela não se assemelhar às colegas de escola por conta de seu peso. De fato, ela associa ambas as coisas, abrindo o primeiro capitulo com a seguinte passagem:

Para quem vem de uma familia que, nos miseráveis e congelados vilarejos judeus da Europa, passou fome de comer só repolho ou só batata, para a qual, naqueles shtetels, carne era uma abstração que os dentes nem conheceram e que se acostumou a aplacar o oco do estômago com sopa de beterraba ou com aquele mameligue, que nada mais era do que um mingau meio insosso de farinha de milho e água, a obsessão por comida nada tem, ou nada deveria ter, de extraordinário (MOSCOVICH, 2007, p. 21).

A obsessão com a comida, considerada uma herança ancestral pela narradora, é um dos fatores que definem a identidade e causam a estranheza daquele que veio de fora. Morando em Porto Alegre, os pais tentam anular a sensação do deslocado colocando a filha no Colégio Israelita. No entanto, a comparação com as colegas apenas acentua isso: "Enquanto minhas colegas frequentavam lojas e butiques nas quais se vendiam roupas para meninas-moças, (...) eu me contentava em cinzentas lojas de confecções para senhoras, nas quais conseguia vestidões, saiões e camisões, tudo o que merecesse superlativos" (MOSCOVICH, 2007, p. 37).

Esse sentimento é novamente ressaltado quando a personagem-narradora se sente diferente e nota a desaprovação de sua mãe em relação a ela:

\begin{abstract}
Eu fui uma criança baixinha, de cabelos crespos e rosto pintado por sardas. A senhora dizia que tinha horror a gente ruiva, que minha prima, de cabelos vermelhos e brilhantes, filha de tia Dvoire, era feia, feia, feia. Eu vivia num pânico secreto: me enxergava quase ruiva no branco da pele e naquelas sardas que, ao sol dos verões na praia, estouravam de ferrugentas. Tinha uma inveja danada das meninas que não eram judias, as góis, cuja tez lisa se bronzeava num castanho tão parelho quanto profundo. A senhora bem que queria uma filha de pele escurecida pelo sol, trigueira, cabelos escorridos, como são as moças nascidas da herança tropical (MOSCOVICH, 2007, p. 49).
\end{abstract}

Moscovich afirma que a condição judaica é fatorial e, a partir dessa ideia, reflete sobre a construção de Por que sou gorda, mamãe?: segundo a autora, a personagem central está obesa e a sua gordura é uma dor não resolvida. Sendo assim, ela busca a origem "desse tormento" na história da família - dai o tom memorialístico da narrativa -, uma procura por identificação e pertencimento. Para Moscovich:

O romance vira uma história de todas as histórias. E na verdade eu acho que ela nunca encontra essa resposta. Mas essa busca de quem ela é, das raizes dela, do que sofreram dá uma linda pista do que ela é. E ela tem esse atrito muito sério com a mãe, que é uma relação de culpa muito severa, irresolvida, e é como se essa menina carregasse esse pesar, que é tudo pelo que passou essa familia, como se a mãe atirasse constantemente na cara dela tudo o que a familia sofreu (MOSCOVICH, 2018, informação oral).

Em Diário da queda, Laub aborda o mesmo tema: 
Alguma coisa muda quando você vê o seu pai repetindo a mesma coisa uma, duas ou quinhentas vezes, e de repente você não consegue mais acompanhá-lo, se sentir tão afetado por algo que aos poucos, à medida que você fica mais velho, aos treze anos, em Porto Alegre, morando numa casa com piscina e tendo sido capaz de deixar um colega cair de costas no aniversário, aos poucos você percebe que isso tudo tem muito pouca relação com a sua vida. Depois que fiquei amigo de João também comecei a olhar para os meus amigos sem entender por que eles tinham feito aquilo, e como eles tinham me cooptado, e comecei a ter vergonha de ter gritado gói filho de uma puta, e isso se misturava com o desconforto cada vez maior diante do meu pai, uma rejeição à performance dele ao falar de antissemitismo, porque eu não tinha nada em comum com aquelas pessoas além do fato de ter nascido judeu. (LAUB, 2011, p. 32)

Com base nesses trechos, pode-se ver como a identidade do judaísmo não é sempre igual e varia com o passar do tempo. No caso do romance de Laub, há um pai cujo próprio pai sentiu na pele as consequências da guerra e do nazismo, gerando um trauma que o fez repetir uma, duas ou quinhentas vezes a mesma história com o mesmo tom de voz. Mas seu filho, quatro décadas depois, tem outra percepção, outras necessidades.

Scliar também ressalta em $A$ condição judaica o questionamento como uma característica essencial do povo. Segundo ele, parte do que significa ser judeu vem do impulso de contestar e rebelar-se. Em outras palavras, ser judeu é ter uma natureza rebelde.

Para embasar sua opinião, o autor cita duas histórias: a primeira é uma passagem biblica na qual o Profeta Eliseu amaldiçoa crianças que o chamaram de careca. A segunda é a fábula "A roupa nova do rei", de Christian Andersen, na qual uma criança denuncia a nudez do rei. Conforme Scliar, os exemplos mostram que os judeus nem sempre aceitavam os designios de autoridades, mesmo que divinas: "Uma conotação de rebeldia, de teimosia, envolve este nome [judeu]; rebeldia e teimosia que depois revelaram-se vitais para a sobrevivência do povo judeu" (SCLIAR, 1985, p. 8-9). Ele ainda completa:

Questionar faz parte da condição judaica. É próprio do judaísmo não aceitar as coisas simplesmente porque elas têm atrás de si o peso da autoridade, e neste sentido os próprios profetas são exemplos eloquentes. Raramente a História viu questionadores tão atrevidos e tão corajosos como os profetas bíblicos, modelos de todos os reformadores sociais (SCLIAR, 1985, p. 9).

É preciso destacar o povo da Diáspora: por conta da sua condição de estrangeiro, onde quer que fosse, via as coisas com os olhos de um estranho - observando o que os outros não viam. Assim, tal como seus antepassados biblicos, o judeu da Diáspora fazia perguntas. Olhos que não deixam de ver o que está certo e o que está errado, o que é justo e o que é injusto, o que é bom e o que é mau (SCLIAR, 1985).

\section{Tradição: rituais, cozinha e humor}

Enquanto a rebeldia e o questionamento fazem parte da condição judaica, o mesmo não acontece quando se fala sobre o assunto como religião. Visto dentro dos limites do dogma religioso, o judaísmo se mostra tão conservador quanto pode ser qualquer outra religião quando praticada com fanatismo.

Os preceitos e a ritualística judaicos são rigorosos, exigentes e, segundo Scliar, "dramáticos", porque, "a par de suas funções simbólicas, o ritual cumpre uma função psicológica importante, que é a de aliviar a ansiedade. Ora, a ansiedade foi o que não faltou na existência tumultuada dos judeus" (SCLIAR, 1985, p. 11).

Essa função de aliviar a ansiedade, a que ele se refere, é subvertida em O diário da queda, de Laub. No livro, o autor transforma a cerimônia do Bar Mitzvá, o ritual de passagem que insere o jovem judeu como um membro maduro na comunidade, no marco no qual se dá o acontecimento dramático que marcará a vida do personagem e o ponto de partida para uma reflexão sobre o trauma:

Praticamente todos os meus colegas fizeram Bar Mitzvah. A cerimônia era aos sábados de manhã. O aniversariante usava talid e era chamado para rezar junto com os adultos. Depois havia um almoço ou janta, em geral num hotel de luxo, e uma das coisas que meus colegas gostavam era de passar graxa nas maçanetas dos quartos. Outra era fazer xixi nas caixas de toalhas dos banheiros. Outra ainda, embora isso só tenha acontecido uma vez, na hora do parabéns, e naquele ano era comum jogar o aniversariante para o alto treze vezes, um 
grupo o segurando nas quedas, como numa rede de bombeiros - nesse dia a rede abriu na décima terceira queda e o aniversariante caiu de costas no chão (LAUB, 2011, p. 6-7).

Não é por acaso que Laub escolhe esse momento. O personagem atualiza de alguma forma o trauma herdado, ao iniciar-se, ao mesmo tempo, no mundo dos adultos e na crueldade arbitrária: "Para mim tudo começa aos treze anos, quando deixei João cair na festa de aniversário..." (LAUB, 2011, p. 33). E, nessas nefastas boas-vindas, o que começa também é um caminho de vergonha e culpa que ele terá de trilhar e que o faz focar o olhar em seu pai e em seu avô, com suas respectivas formas de encarar a dor.

Enquanto Laub trabalha sua narrativa desde uma revisita ao trauma, numa perspectiva geracional e masculina, ao aprofundar nos personagens do filho-narrador, do pai e do avô, Moscovitch, em Por que sou gorda, mamãe?, entrega uma história baseada fundamentalmente nos vínculos femininos e se vale de uma estratégia diametralmente oposta para contá-la: o humor. O romance da autora se organiza como um grande monólogo dirigido à mãe:

O Criador não pode estar em todos os lugares, por isso criou as mães - outra máxima que brilha em nosso amarissimo folclore. Pesa, como isso pesa. Porque desde cedo a mãe judia, sócia do Senhor na criação da vida, ensina que vai nos levar pela mão e que vai nos dar alegria. Os filhos não sabem nada, só ela sabe. e nós, os filhos, podemos confiar em Deus e nela, talvez não nessa ordem, que às vezes Deus se distrai. A senhora, mamãe, norte de nossa vida, capaz de despertar o próprio sono do Senhor (MOSCOVICH, 2007, p. 153).

Muitas vezes associado ao personagem dessa matriarca, autoritária, escandalosa e, geralmente, gorda, o peculiar humor judaico está sempre nos limites entre crueldade e gentileza. Scliar (1985, p. 43) o descreve como "um humor agridoce, melancólico, um humor meio-sorriso, não de risos. Um humor que serve de veículo para a sátira aos ricos, aos poderosos, sem perder de vista as fraquezas humanas".

É esse humor difícil e, por vezes, dolorido que Moscovich usa para falar, de um jeito aparentemente leve, de dores e de frustrações profundas.
A narradora-protagonista de Por que sou gorda, mamãe? é uma mulher obesa, de meia-idade, que trava uma luta contra os hábitos alimentícios que the foram ensinados como parte da cultura dos seus. O que leitor tem em mãos é, na verdade, a dificuldade de uma relação mãe-filha atravessada por manipulação e culpa, e que, na incompetência emocional para expressar o amor, se valeu sempre da comida como compensação.

A cozinha é um grande centro de qualquer tradição, sendo a culinária kosher a designação que reúne todos aqueles alimentos que obedecem à lei judaica. Com um lugar de destaque muito mais importante do que em outras religiões, a escolha, preparação e ingestão alimentar estão associadas à ritualística ao ponto de Scliar asseverar que os alimentos consumidos por eles, "comida de pobre ou não, caracterizaram a culinária judaica, fator de coesão grupal: o judaísmo consolidou-se, em grande parte, na mesa da cozinha" (SCLIAR, 1985, p. 17).

Em Por que sou gorda, mamãe?, Moscovich oferece inúmeras passagens que dão conta de ratificar essa ideia:

\begin{abstract}
Nós nos reuníamos em torno da mesa, em torno da vó, em torno dos pratos - em torno da comida que ela tratava como uma cerimônia de milagre. E ela abria os braços para nos acarinhar a todos, e nos beijava com os lábios finos, o hálito de menta, e pronunciava palavras boas, palavras de quem traz alvissaras, feliz como quem pode dar o seio a um bebê: minhas crianças, a vó trouxe comida para vocês (MOSCOVICH, 2007, p. 94)
\end{abstract}

Em entrevista, a escritora recorreu à experiência pessoal para explicar o que ela considera que estaria por trás dessa característica:

Para os imigrantes, e também para os judeus que ficaram na Europa, comida sempre significou um presente muito grande. Significou a sobrevivência. Então a comida, para a nossa gente, principalmente os judeus que viviam no leste europeu, pela escassez de comida, para nós, do novo mundo, uma forma nobilissima de demonstração de afeto sempre foi fazer uma mesa farta e oferecer comida. Para nós, essa é a forma mais nobre de oferecer afeto (MOSCOVICH, 2018, informação oral).

São justamente os desdobramentos e as repercussões dessa mesa sempre farta como milagre 
nutritivo, depois de tanta fome e da cozinha como principal matriz do afeto judaico, o mote que faz avançar a trama do romance. Moscovich utiliza um traço identitário concreto e prosaico, como é a comida na cultura desse povo, para falar sobre questões como os vínculos afetivos familiares que, embora estejam profundamente marcadas pela condição judaica, vão muito além dela: são humanas.

\section{Considerações finais}

A partir do exame de duas obras que contemplam a identidade judaica - Por que sou gorda, mamãe?, de Cíntia Moscovich (2006), e Diário da queda, de Michel Laub (2011) -, é possivel verificar que ela, tal como estudada por Moacyr Scliar e demonstrada pelas narrativas ficcionais e pelas entrevistas realizadas com os autores, não se consubstancia por qualquer dado geográfico ou biológico, nem estritamente religioso. Essa identidade pode ser vista sim pela cultura, que se manifesta em múltiplas expressões, seja da arte, seja da vivência cotidiana, seja pela sua via historicamente privilegiada, a da literatura.

Uma ideia de literatura judaica, portanto, não é facilmente depurada como gênero, escola ou agrupamento de obras que possam ser classificadas a partir de uma marca especifica. Esse conceito perpassa uma série de elementos complexos - autoria, tema, abordagem, representação, objetivo -, de difícil categorização.

Entretanto, é possivel afirmar, com base na análise das obras citadas e na visão in loco de seus autores, que a literatura brasileira contemporânea apresenta uma expressão representativa do judaísmo como cultura. O pensamento, a memória e o cotidiano judaico são ricamente representados nas narrativas, e seus autores e obras têm expressivo reconhecimento no cenário literário, o que tem se mostrado altamente valoroso do ponto de vista da diversidade cultural do pais.

\section{Referências}

BOSI, Ecléa. O tempo vivo da memória: ensaios de psicologia social. São Paulo: Ateliê Editorial, 2013.

CANDAU, Joël. Memória e identidade. Tradução Maria Leticia Mazzucchi Ferreira. São Paulo: Contexto, 2011.
DELUMEAU, Jean. História do medo no ocidente. Tradução Maria Lucia Machado, tradução de notas: Heloísa Jahn. São Paulo: Companhia das Letras, 2009.

LAUB, Michel. Diário da queda. São Paulo: Companhia das Letras, 2011.

LAUB, Michel. Michel Laub: depoimento [set. 2018]. Entrevistadores: Bibiana Barrios Simionatto, Daniel Fernando Gruber, Frederico Dollo Linardi, Luiz Antonio de Assis Brasil, Maria Elena Morán Atencio, Mariana Pessah, Stéfanie Garcia Medeiros. Porto Alegre: PUCRS, 2018. Arquivo digital, 39:19 min. Entrevista concedida ao Projeto A condição judaica no processo de criação literária de Cintia Moscovich e Michel Laub.

MOSCOVICH, Cintia. Por que sou gorda, mamãe? Rio de Janeiro: Record, 2007.

MOSCOVICH, Cintia. Cintia Moscovich: depoimento [set. 2018]. Entrevistadores: Bibiana Barrios Simionatto, Daniel Fernando Gruber, Frederico Dollo Linardi, Luiz Antonio de Assis Brasil, Maria Elena Morán Atencio, Mariana Pessah, Stéfanie Garcia Medeiros. Porto Alegre: PUCRS, 2018. Arquivo digital, 53:10 min. Entrevista concedida ao Projeto A condição judaica no processo de criação literária de Cintia Moscovich e Michel Laub.

PFEFFER, Renato Somberg. Vidas que sangram história: a comunidade judaica de Belo Horizonte. Belo Horizonte: C/Arte: FACE-FUMEC, 2003

SALLES, Cecilia Almeida. Gesto inacabado. São Paulo: Intermeios, 2014.

SARLO, Beatriz. Tiempo pasado: cultura de la memoria y primera persona. México: Siglo XXI Editores, 2006.

SCLIAR, Moacyr. A condição judaica: das Tábuas da lei à mesa da cozinha. Porto Alegre: [s. n.], 1985.

\section{Luiz Antonio de Assis Brasil}

Doutor em Letras pela Pontificia Universidade Católica do Rio Grande do Sul (PUCRS), professor da Escola de Humanidades da PUCRS.

Daniel Fernando Gruber

Doutor em Letras pela Pontificia Universidade Católica do Rio Grande do Sul (PUCRS).

\section{Bibiana Barrios Simionatto}

Mestre em Letras pela Pontifícia Universidade Católica do Rio Grande do Sul (PUCRS).

\section{Frederico Dollo Linardi}

Doutorando em Letras pela Pontifícia Universidade Católica do Rio Grande do Sul (PUCRS). 
22 Letras de hoje Porto Alegre, v. 55, n. 2, p. 213-222, abr.-jun. 2020 | e-36469

\section{María Elena Morán Atencio}

Doutoranda em Letras pela Pontificia Universidade Católica do Rio Grande do Sul (PUCRS).

\section{Mariana Pessah}

Graduada em Escrita Criativa pela Pontifícia Universidade Católica do Rio Grande do Sul (PUCRS).

\section{Stéfanie Garcia Medeiros}

Doutoranda em Letras pela Pontificia Universidade Católica do Rio Grande do Sul (PUCRS).

\section{Endereço para correspondência}

Pontificia Universidade Católica do Rio Grande do Sul (PUCRS), prédio 8.

Av. Ipiranga, 6681 - Partenon

Porto Alegre - RS

CEP: $90619-900$ 